熱帯林における空中写真材積表の分析と調製

\title{
Making Photo Volume Tables of the Tropical Forest
}

渡辺 宏*・望月 潔*
水上 正昭*

\begin{abstract}
A photo volume table is indispensable to an inventory of forest resources. Especially in the tropical forest, the practical use of aerial photographs are very useful because of the difficult accessibility.

We would like to explain the analysis of volume estimation formulas and the making of photo volume tables about Merkusii pine (Pinus Merkusii) in Indonesia and Coconut tree (Cocos Nucifera) in Fiji.
\end{abstract}

\section{1.はじめに}

林業に扔ける空中写真活用の歴史は, 古く第 2 次世 界大戦前から，樺太，満州などの森林調査に導入され 現在に至っている ${ }^{1)}$ 。その間, 国土の $2 / 3$ を占める 林野の森林基本図（縮尺 $1 / 5,000 ）$ の整備 ${ }^{2}$ ), 森林 資源調查 ${ }^{3}$ ， そして最近は社会経済の発展に伴なって 生じてきた森林のもつ公益的機能発揮のための調査設 計 $^{4)}$ など, 多方面に活用されている。

これらの空中写真の活用法は, 年々増加してゆく人 件費を含む調査経費, そして減少してゆく調査日数と いった，最近の国内林業情勢に対して，作業効率の向 上, 調査精度の向上に不可欠なものとして役立ってい るが，空中写真の技術が真に威力を発揮するのは，熱 帯地域を主とする発展途上国においてではないかと思 われる。

現在, 日本の木材需給は, その $65 \%$ が外材によって まかなわれている。そしてそのうち過半の $50 \%$ 強が発 展途上国からの，いわゆる南洋材である ${ }^{5)}$ 。しかしこ れら発展途上国の森林も, 有用な天然林の大方はかな りの伐採が進んで来ている。また資源ナショナリズム の高揚などから, 計画的な伐採およびそのための確実

\footnotetext{
*日本林業技術協会

写真測量とリモートセンシング Vol.16, №. 3, 1977

な資源調査の実施や, 新たな森林の造成 (人工林植栽), あるいは未利用樹種の需要開発などを要求するケース が増えてきている。すなわち, 地形, 土地利用, そし て林相に関して最大の情報源である空中写真が活用さ れる由縁である。

とくに人工造林については, F AOの勧告, 先進国 の技術的，資金的援助などによって除々に実施されつ つあり ${ }^{6)}$ ，中にはその旺盛な生長状態から伐期に達し たものもあり, いずれ近い将来にこうした森林が増加 してくることが予想されている。これらの森林は, 人 工林とはいえ, やはり交通不便で労働効率の悪い山間 部にあり，その調査には空中写真を出来るだけ利用す ることが得策と思われる。

ここでは, これらの情勢に先がけて, 熱帯の森林資 源調査に空中写真を活用する場合のかなめとも言うべ き空中写真材積表を, インドネシアのメルクシーマッ と, フィジーのココナツについて分析, 調製した結果 を報告する。

\section{2. 空中写真材積表の分析手法}

樹木 (単木) や森林全体の材積を現地において測定 することは容易なことではないから, 空中写真上で測 定が可能で, 材積と関係の深いいくつかの要因を媒体 として間接的に推定することを考える。このための換 算式を空中写真材積式と言い, それを使い易いように 
索引表の形に調製したものが空中写真材積表である ${ }^{7)}$ 。

空中写真材積式の誘導は, 樹種, 地域特性が均質と みなせる範囲から抽出した数多くの標本について, 現 実の材積を現地で，また要因の值を空中写真上で測定 し，これをいくつかの適当な関数式にあてはめて回帰 分析を行なう。そして分析精度の最もよい関数式およ びそのときのパラメーターをもって材積式とするので ある。この場合, 用いる関数式は次のものがよく適応 するとされている。

1 要因では, $Y=a+b \cdot X$

$$
\begin{aligned}
& Y=a \cdot X^{b} \\
& Y=a+b \cdot X+c \cdot X^{2}
\end{aligned}
$$

2 要因では, $Y=a+b \cdot X_{1}+c \cdot X_{2}$

$$
\begin{aligned}
& \mathrm{Y}=\mathrm{a} \cdot \mathrm{X}_{1}^{\mathrm{b}} \cdot \mathrm{X}_{2}^{\mathrm{c}} \\
& \mathrm{Y}=\left(\mathrm{a}+\mathrm{X}_{1}\right) \cdot\left(\mathrm{b}+\mathrm{X}_{2}\right)
\end{aligned}
$$

3 要因では, $Y=a+b \cdot X_{1}+c \cdot X_{2}+d \cdot X_{3}$ など,

また要因としては, 単木に対して樹高, 樹冠直径, 林分に対しては平均樹高, 樹冠疎密度, 立木本数, 平 均樹冠径などが考えられる。いずれにしても材積と相 関が高いことが第 1 条件であり, 写真上で測定がしや すいことも実行上の配慮として大切なことである。

空中写真材積表には, 単木材積を推定する場合の空 中写真立禾材積表と，林分としての材積を推定する場 合の空中写真林分材積表とがある。以下分析調製を行 なった 3. は後者の例であり，4. 洋前者の例である。

\section{3.インドネシア・メルクシーマツの場合}

\section{1) メルクシーマツの概要}

メルクシーマッ(Pinus Merkusii)は, インドネシア, マレーシアで多く造林され，フィリッピン，ニューギ ニア，フィジー，ニューカレードニアでも試験的に造 林されている熱帯地方の代表的な松である。材の色調 は淡赤色ないし赤色で, その解剖学的性質はアカマツ, クロマッなど温帯産の松と同じで, 建築, 造作, 杭, パルプ用材として用いられている。

インドネシアでは, 特に中部ジャワあるいは北スマ トラ等の高原地帯に, 戦前からかなり広面積に造林さ れており, 現在では 30 年生ないし 40 年生のものもか なり見受けられる。中部ジャワ高原地带は, 温暖多雨 な気候によりその生長は良好で， $20 \sim 30$ 年生で樹高 は $20 \sim 30 \mathrm{~m}$ ，胸高直径は $20 \sim 40 \mathrm{~cm}$ に達する。こ >
のメルクシーマツは, 植後約 11 年から 30 年位までそ の樹幹下部から松脂を採取し，この松脂は主にバティ ック (ろうけつ染) 工業, 石けんの原料, 製紙のサイ ジング用として用いられている。最近では，この松脂 採取後のメルクシーマツがパルプ用材として注目され はじめ, メルシーマッの資源量把握，その伐採更新法 など，永続的な森林経営計画の樹立が急務となってい る。

\section{2）サンプルプロットの抽出}

今回メルクシーマッの空中写真林分材積表を作成し た地域は，インドネシア国中部ジャワ州西プカロンガ ン営林署管内の国有林, 約 35,000ha の内, III 齢級以 上（1969年以前の植栽）のメルクシーマツ造林地であ る。対象地域の位置図を図一 1 に示寸。

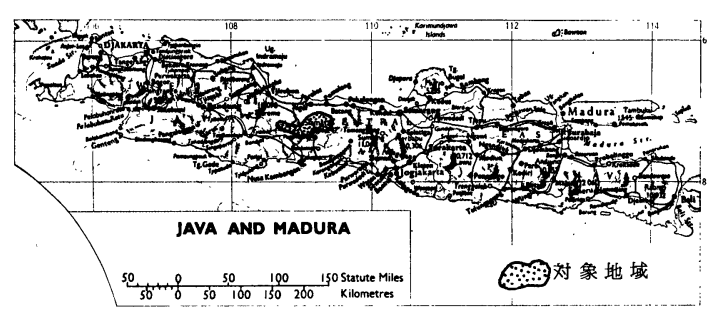

\section{図ー 1 メルクシーマツ空中写真材積表作成对象地域位 置図}

サンプルプロットの抽出は，この材積表を種々の地 形を有する広域の対象地全域に，かつ III齢級以上の種 種の林齢に適用できるものとするため，しかも短期閒 で高精度のものを作成するために任意抽出によった。

まず林小班毎にマツの植栽年度の記入されている当 営林署管内図を使って, 地域的にも林㱓的にもまんべ んなくプロットが抽出できるように，プロット予定林 小班を選定した。次にサンプルプロットが樹高, 樹冠 疎密度等の林相においてさまざまな状態の林分にばら まかれるようにするために, 先の対象林小班を空中写 真判読によって森林区画を行なった。この森林区画基 準は, 齢級, 林相, 樹高階, 樹冠疎密度階によって行 なっている。

これらによって, サンプルプロットが種々の林況要 因, カテゴリーを満たすよう, また地形的（標高, 方 位, 傾斜, 局所地形にも偏りのないように, あらかじ め机上でプロット予定林分を抽出し, 細かいプロット の位置は現地で選定した。結局, サンプル数は作業功 

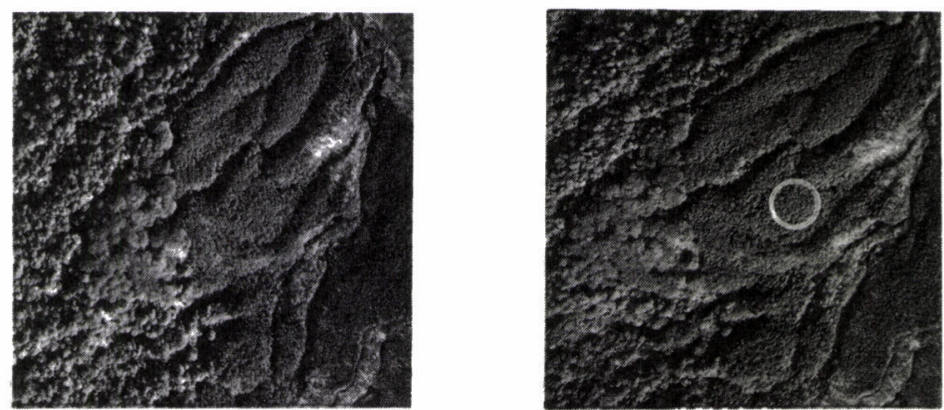

写真一 1 メルクシーマツ空中写真の一例

撮影縮尺 $1 / 20,000$ の密着写真, 撮影高度 4, $360 \mathrm{~m}$, 中央がメ ルクシーマツ人工林, 左端は広葉樹天然林

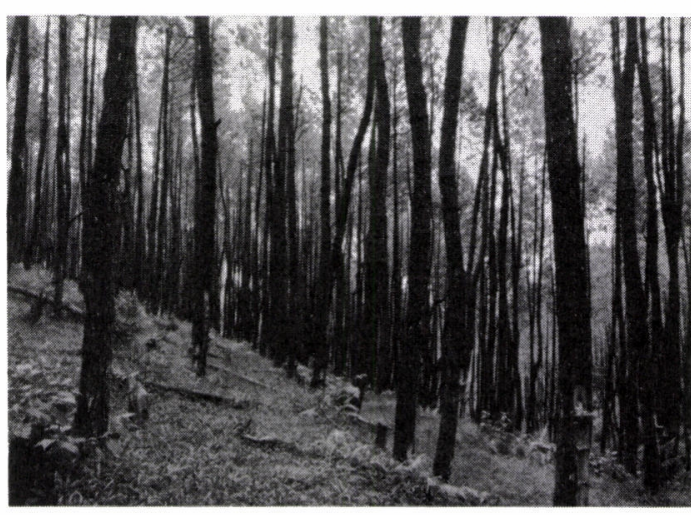

写真-2 プロットの現地写真 (空中写真の○印位置) $\mathrm{V}$ 齢級（1958 年植栽）平均樹高 $20.5 \mathrm{~m}$ 平均胸高直径 $23.3 \mathrm{~cm}$ ha 当り本数 816 本 $\mathrm{h}$ a 当り材積 $213 \mathrm{~m}^{3}$, 幹に松脂採集のための 切口が見える。

程も加味し, 88 点を抽出した。

\section{3）プロットの現地調査}

サンプルプロットは, $50 \times 50 \mathrm{~m}$, 面積 0.25 ha の 方形区とし，現地においてまず周囲測量を行なった。 その起点を空中写真上に刺針し，プロットの設定方向 角も記録しておいた。プロット内の立木については次 の事項を調査した。

樹高, 胸高直径, 立木本数, 林齢

以上の現地調查の結果から, プロット毎に, 平均樹 高, 平均胸高直径, 林分材積 (ha当り) を集計計算し た。

サンプルプロットの森林状態の一例を, 空中写真と 現地の写真により示す（写真一 1, 2)。

4）プロットの罙中写真判読

一方, 空中写真上でも, 林分平均樹高, 立木本数,
樹冠疎密度の林況要因を判読した。判読に使用した空 中写真は，撮影縮尺約 1／20,000の密着写真である。 たぶし一般的には 3 倍の双眼鏡付き立体鏡を用いるが， 今回は 6 倍の双眼鏡付きを用いて判読精度の向上に努 めた。

作業は, まずプロット設置方向角をもとに空中写真 上にプロットサイズ板によってプロットを設定した。 各要因の判読の際は, 縮尺 $1 / 20,000$ で 0.2 ha の正 方形のプロットとし, 最後にプロットの標高によって 判読值の縮尺補正をしていった。

樹高の判読については，まずプロットの基線長を測 定し, 次に写真上のプロット内の平均的な林木を 5 本 程度選び，これら林木の梢端と根元の視差々を視差測 定桿によって測定し, 平均視差々を計算した。樹高の 計算式は次によった。

$$
\mathrm{h}=\frac{\mathrm{H}_{\mathrm{o}}-\mathrm{H}_{\mathrm{p}}}{\mathrm{b}+\triangle \mathrm{P}} \times \triangle \mathrm{P}
$$

$$
\begin{aligned}
& \mathrm{h}: \text { 樹高 } \\
& \mathrm{H}_{\mathrm{o}} \text { : 撮影高度 } \\
& \mathrm{H}_{\mathrm{p}}: \text { プロット位置標高 } \\
& \mathrm{b}: \quad " \quad \text { 基線長 } \\
& \triangle \mathrm{P}: \text { 視差々 }
\end{aligned}
$$

本数は, 前述のように立体視しながら, プロット内 に入る本数を 10 本単位に 3 回数え, その平均值をプロ ット判読本数とした。そして次式によって縮尺補正を 行ないつつha当り本数に換算した。

$$
\mathrm{N}=\mathrm{N}_{\mathrm{p}} \times \frac{1}{0.2 \times\left(\frac{\mathrm{S}}{20,000}\right)^{2}}
$$

\section{$\mathrm{N}:$ ha 当り本数}

$\mathrm{N}_{\mathrm{p}}:$ プロット判読本数

$S:$ プロット位置写真縮尺分母数 
また本数とともに，プロット内の樹冠柾密度を $5 \%$ 単位に 3 回測定し, その平均值を樹冠疎密度判読值と した。

\section{5）判読精度の分析}

空中写真林分材積表に最も重要な因子である平均樹 高と本数について, 判読值と実測値の比較検討を行な い, 判読の精度を調べた。各プロットの判読樹高と現 地調查結果のプロット平均樹高, 判読ha当り本数と現 地調査ha当り本数について相関の計算を行ない, 相関 係数と回帰直線式を求めると次のようになった。

平均樹高: $y=0.8282 x+6.7449$

$$
(\rho=0.9404)
$$

ha当り本数: $y=1.3887 x-57.1138$

$$
(\rho=0.8984)
$$

\section{（注） $y$ : 判読値, $x$ : 実測値}

式に見られるように, 平均樹高, ha当り本数とも実測 值よりかなり下回って判読されているが, その判読の 傾向はほぐ一定であり, 相関係数はどちらも0.9 前後 となっている。従ってこれらの判読値は空中写真材積 表作成のためのデータとして充分使用可能なものと判 断した。

\section{6）材積式の第 1 次分析}

前項によって, 平均樹高とha当り本数はかなり高い 精度で判読されていることがわかった。また樹冠疎密 度も空中写真上では比較的容易に測定のできる要因で ある。従って空中写真林分材樍式分析のための要因と しては，とりあえずこれら 3 つ要因を対象とするこ ととした。材積は現地調査結果の各プロットのha当り 材積である。

ところで材積式の分析に当っては上記 3 要因のうち 2 要因を抽出し, 各種の材積式にあてはめ重回帰分析 計算を行なって比較している。2 要因にしぼったのは, 材積表の形に調製したとき索引がしやすいことを配虑 したためである。あてはめに用いた材積式, および使 用要因は次の通りである。

$$
\begin{aligned}
& \text { ケース } 1 \text { （使用因子 } \mathrm{H}, \quad \mathrm{N} \text { ) } \mathrm{V}=\mathrm{a}_{1} \mathrm{H}+\mathrm{b}_{1} \mathrm{~N}+\mathrm{c}_{1} \\
& \text { " } 2(" \prime \mathrm{H}, \mathrm{D}) \mathrm{V}=\mathrm{a}_{2} \mathrm{H}+\mathrm{b}_{2} \mathrm{D}+\mathrm{c}_{2} \\
& \text { " } 3(\quad \text { ( } \mathrm{H}, \quad \mathrm{N}) \log \mathrm{V}=\mathrm{a}_{3} \log \mathrm{H}+\mathrm{b}_{3} \\
& \log \mathrm{N}+\mathrm{c}_{3} \\
& \text { " } 4 \text { ( } \quad \text { " } \mathrm{H}, \quad \text { D) } \log \mathrm{V}=\mathrm{a}_{4} \log \mathrm{H}+\mathrm{b}_{4} \\
& \log \mathrm{D}+\mathrm{c}_{3}
\end{aligned}
$$

" $5(\quad$ ( $\mathrm{H}, \mathrm{N}) \mathrm{V}=\mathrm{a}_{5} \mathrm{H}+\mathrm{b}_{5} \mathrm{~N}^{2}+\mathrm{c}_{5}$

\begin{tabular}{|c|c|c|}
\hline $\begin{array}{l}\text { ケー } \\
\text { ス No. }\end{array}$ & 材＼cjkstart積 & $\begin{array}{l}\text { 重 相 } \\
\text { 関 係 数 }\end{array}$ \\
\hline 1 & $\begin{aligned} \mathrm{V}= & 13.0979 \mathrm{H}+0.2133 \mathrm{~N}- \\
& 116.8899\end{aligned}$ & 0.9257 \\
\hline 2 & $\begin{aligned} \mathrm{V}= & 11.5333 \mathrm{H}+1.8701 \mathrm{D}- \\
& 132.1929\end{aligned}$ & 0.9239 \\
\hline 3 & $\begin{aligned} \log \mathrm{V}= & 1.1324 \log \mathrm{H}+0.5033 \log \mathrm{N} \\
& -0.9185\end{aligned}$ & 0.9349 \\
\hline 4 & $\begin{aligned} \log V= & 0.9852 \log \mathrm{H}+0.4826 \log \mathrm{D} \\
& +0.4407\end{aligned}$ & 0.9098 \\
\hline 5 & $\begin{aligned} \mathrm{V}= & 12.5524 \mathrm{H}+0.0002 \mathrm{~N}^{2}- \\
& 58.6465\end{aligned}$ & 0.9067 \\
\hline
\end{tabular}

(注) $\mathrm{V}: \mathrm{ha}$ 当り材積 (実測值)

$\mathrm{H}:$ 平均樹高 (判読值)

$\mathrm{N}:$ ha当り本数 $(" \prime)$

$\mathrm{D}:$ 樹冠疎密度 ( $\prime \prime)$

計算の結果は，表一 1 の通りである。なおデータ数 は樹冠疎密度が極めて 疎で各要因の判読が不能な 8 点 を棄却した 80 点である。

表一 1 材積式の第 1 次分析結果 (メルクシーマッ)

表によれば，ケース 3 の樹高と本数を自然対数の変 数とする材積式が重相関係数 0.9349 と最も高く, 次 いでケース 1 が 0.9257 となっている。すなわち樹高 と本数を要因とする材積式の方が，樹冠疎密度を含む 材積式よりも精度が良い。

もう一つの精度のメルクマールとして, 分析に用い たデータの材積値についての実測值と求めた材積式に よる推定値の差の標準偏差, および標準誤差率（差の 標準偏差／実測值の平均) $\times 100$ をケース 1 とケース 3 について求めると表一 2 となった。

これによると，ケース 3 は重相関係数はケース 1 よ

\begin{tabular}{c|c|c|c}
\hline ケースNo. & 残 差の平均 & 残差の標準偏差 & 標準誤差率 \\
\hline 1 & 25.697 & 16.618 & $9.11 \%$ \\
\hline 3 & 25.937 & 18.708 & $10.25 \%$ \\
\hline
\end{tabular}

\section{表一 2 残差による精度分析結果（メルクシーマッ）}

りも若干良いものの，標準誤差率においてや>精度が 下回わることがわかった。したがって今回の材積式と してはケース 1の式を採用することにした。 


\section{7）材積式の第 2 次分析}

ところでこのケース 1 の計算結果を，実測值と推定 值の比較によって哈味すると, 使用データのうち 1 点 がかなり異常な推定值を示し残差が大きいことが判明 した。これは要因の判読において過誤があったものと 推察される。そこでこの1点を棄却し，データ数79で 再計算を行なうと表一 3 のような材積式および精度を 得た。結果は重相関係数, 標準誤差率ともに高い精度 を示し空中写真材積表として適当なものと判断される。

\begin{tabular}{l|c}
\hline 材 積 式 & $\mathrm{V}=13.1619 \mathrm{H}+0.2121 \mathrm{~N}-116.3809$ \\
\hline 重相 関係数 & 0.9328 \\
\hline 残差 差平均 & 24.938 \\
\hline 残差の標準備差 & 15.261 \\
\hline 標 淮 誤差率 & $8.36 \%$ \\
\hline
\end{tabular}

表一 3 材積式の第 2 次分析結果表 (メルクシーマッ)

なお参考までに再計算による実測値と推定値の相関 関係は次の通りである。

$y=0.9999976 x+0.0016937$

$(y:$ 実測值, $x$ : 推定值)
また各要因の単相関行列は表一 4 の通りで，材積推定 には樹高が大きく効いていることが推察される。

\begin{tabular}{lc|r|r|r}
\hline \multicolumn{2}{c|}{ 子因 } & \multicolumn{1}{c|}{ 樹 高 } & \multicolumn{1}{c|}{ 本 数 } & \multicolumn{1}{c}{ 材 積 } \\
\hline 樹 & 高 & 1.0000 & -0.5251 & 0.8412 \\
\hline 本 & 数 & -0.5251 & 1.0000 & -0.0987 \\
\hline 材 & 積 & 0.8412 & -0.0987 & 1.0000 \\
\hline
\end{tabular}

表一 4 要因の単相関行列 (メルクシーマッ)

\section{8）材積表の調製}

最後に，前項で適当と判断した材積式に，順に樹高 值と本数值を代入して樹高と本数の組合わせに応ずる 材積值を算出し、これを一覧表として空中写真林分材 積表をとりまとめた。その一部を表一 5 として示す。

なお，材積式算出に使用しているデータは次の範囲 のものである。

$$
\begin{array}{lc}
\mathrm{V}: & 34.4 \leqq \mathrm{~V} \leqq 359.4 \mathrm{~m}^{3} \\
\mathrm{H}: & 4 \leqq \mathrm{H} \leqq 30 \mathrm{~m} \\
\mathrm{~N}: & 100 \leqq \mathrm{~N} \leqq 850 \text { 本 }
\end{array}
$$

PHOTO VOLUME TABLE (10-1)

SPECIES: PINUS MERKUSII

\begin{tabular}{|c|c|c|c|c|c|c|c|c|c|c|c|c|c|c|c|c|}
\hline \multirow{3}{*}{\multicolumn{2}{|c|}{$\mathrm{H}(\mathrm{m})$}} & \multirow{2}{*}{\multicolumn{15}{|c|}{ NUMBER OF TREES perHA. }} \\
\hline & & & & & & & & & & & & & & & & \\
\hline & & 100 & 110 & 120 & 130 & 140 & 150 & 160 & 170 & 180 & 190 & 200 & 210 & 220 & 230 & 240 \\
\hline \multirow{17}{*}{ 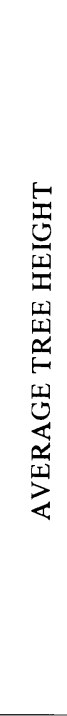 } & 4 & - & - & - & - & - & - & - & - & - & - & - & - & - & - & - \\
\hline & 5 & - & - & - & - & - & - & - & - & - & - & - & - & - & - & - \\
\hline & 6 & - & - & - & - & - & - & - & - & - & - & - & - & - & - & - \\
\hline & 7 & - & - & - & - & - & - & - & - & - & - & - & - & - & - & - \\
\hline & 8 & - & - & - & - & - & - & - & - & - & - & - & - & 36 & 38 & 40 \\
\hline & 9 & - & - & - & - & - & - & 36 & 38 & 40 & 42 & 44 & 47 & 49 & 51 & 53 \\
\hline & 10 & 36 & 39 & 41 & 43 & 45 & 47 & 49 & 51 & 53 & 56 & 58 & 60 & 62 & 64 & 66 \\
\hline & 11 & 50 & 52 & 54 & 56 & 58 & 60 & 62 & 64 & 67 & 69 & 71 & 73 & 75 & 77 & 79 \\
\hline & 12 & 63 & 65 & 67 & 69 & 71 & 73 & 75 & 78 & 80 & 82 & 84 & 86 & 88 & 90 & 92 \\
\hline & 13 & 76 & 78 & 80 & 82 & 84 & 87 & 89 & 91 & 93 & 95 & 97 & 99 & 101 & 104 & 106 \\
\hline & 14 & 89 & 91 & 93 & 95 & 98 & 100 & 102 & 104 & 106 & 108 & 110 & 112 & 115 & 117 & 119 \\
\hline & 15 & 102 & 104 & 107 & 109 & 111 & 113 & 110 & 117 & 120 & 121 & 123 & 126 & 128 & 130 & 132 \\
\hline & 16 & 115 & 118 & 120 & 122 & 124 & 126 & 128 & 130 & 132 & 135 & 137 & 139 & 141 & 143 & 145 \\
\hline & 17 & 129 & 131 & 133 & 135 & 137 & 139 & 141 & 143 & 146 & 148 & 150 & 152 & 154 & 156 & 158 \\
\hline & 18 & 142 & 144 & 146 & 148 & 150 & 152 & 154 & 157 & 159 & 161 & 163 & 165 & 167 & 169 & 171 \\
\hline & 19 & 155 & 157 & 159 & 161 & 163 & 166 & 168 & 170 & 172 & 174 & 176 & 178 & 180 & 182 & 185 \\
\hline & 20 & 168 & 170 & 172 & 174 & 177 & 179 & 181 & 183 & 185 & 187 & 189 & 191 & 194 & 196 & 198 \\
\hline
\end{tabular}

AREA : WEST PEKALONGAN, CENTRAL JAVA

(UNIT: $\mathrm{m}^{2} / \mathrm{ha}$ ) 


\section{4. フィジー・ココナツの場合}

\section{1）ココナツ樹の概要}

熱帯地域の発展途上にある国々の重要な輸出資源と なっているコプラ（石けんやマーガリンの原料となる） は，ココナツの果実から採取する。ココナツ (Cocos Nucifera) はやせた土地にも比較的容易に栽培できるこ とから, 現在東南アジアや太洋州の各地においてプラ ンテーションとして広く植栽されており，これらの国 の主要な産業の一つとなっている。すなわち, ココナ ツは従来樹木というよりも農作物としてとり扱かわれ て来た。

しかしながら最近，ココナップランテーションにと ってひとつの大きな問題が提起されて来た。すなわち, プランテーションとして植栽されたココナツは，果実 の採取を続けると $40 \sim 50$ 年で老龄化し, 結果的に単 位面積当りのコプラの生産量が低下し, 産業としての プランテーションの経営を危うくして来たのである。 長年にわたる植民地時代を通じて積極的に植栽された 各国のココナツプランテーションの大半はいままさに こうした状態にあるとみられ，国の主要産業の維持増 進のために何らかの対策をたてねばならない状態にせ まられている。

このためには老龄化したココナツ林の更新をすみや かに行ない，若々しい林に転換することであるが，単 に更新するにとどまらず，そのために大量に伐採する ココナツの幹を木材として有効に活用し，プランテー ション全体としての収益をいかに高めるかといった点 が問題となって来た。すなわちココナツ樹を木材とし て，そしてココナップランテーションを森林としてと らえる必要が生じたのである。

もっともココナツの樹幹は, 木材とは組織の成り立 ちが異なって扔り，維管束が基本組織の中に不規則に 散在しているので, 柔細胞の占める率が高く, 従来の 木材と性質を異にする。また内側のと外側の比重の差 が非常に大きいといった問題があり，その活用にはか なりの技術開発が必要とされているが，現在までのと ころ用途としては，生産地における手工業的手法によ る工芸品, 装飾的家具, パネル, 床板などの生産が行 なわれている。そして木炭, 活性炭の製造, パーティ クルボードの製造, 杭あるいは電柱などへの利用も試 みられており，更には世界的な老齡過熱木の産業的対
策として, パルプ用材のチップ化の研究も行なわれて いる ${ }^{8)}$ 。

いずれにしても，南太平洋諸国だけでも 46 万ha とい われるココナツ林の樹木としての材積調査が国際問題 として大きくクローズアップして来た。

\section{2) 使用データ}

こ〉で分析する対象は単木材積であり，そのために 使用するデータは標本木から採る。この標本木を抽出 した対象範囲はフィジー国の第 3 の島タベウニ島であ る(図- 2 参照)。

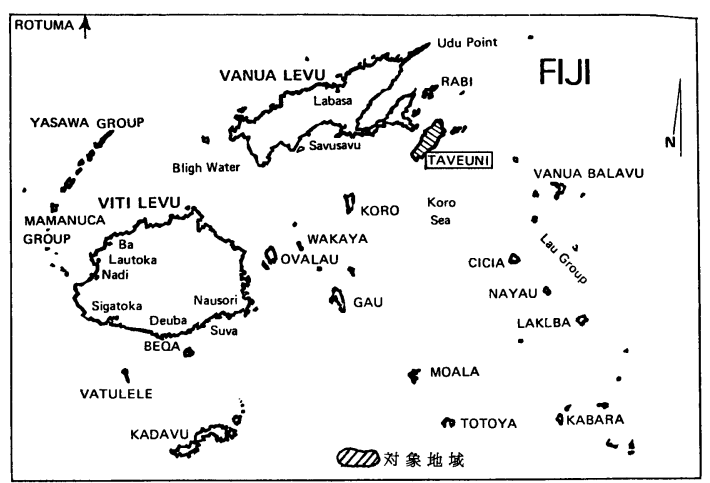

図ー2 ココナツ空中写真材積表作成対象地域位置図

標本木の選定は，この調査と同時に実施したサンプ リング材積調査用として, 対象地から無作為に抽出し たサンプリングプロットがあったので，原則としてそ のプロットの原点の至近木をあてることとした。標本 数は 178 である。

\section{3）標本木の現地調査}

現地に拝いて標本木を決定したのち, 標本木につい て次の要因を調查した。

樹高（根元から葉頂までの高さ), 葉下高(樹幹だ けの高さ), 樹幹中央径, 樹冠直径

測定は, 樹高, 葉下高はブルーメライス, 樹幹中央径, 樹冠直径はレラスコープを用いた。

\section{4）要因の検討}

ココナッを樹木としてとらえ，その材積に関する性 質を分析するのは今回が初好であるから，事前にど の要因が材積と相関が高いのかといったことについて 十分検討がなされ和ばならない。そこで考えられる要 

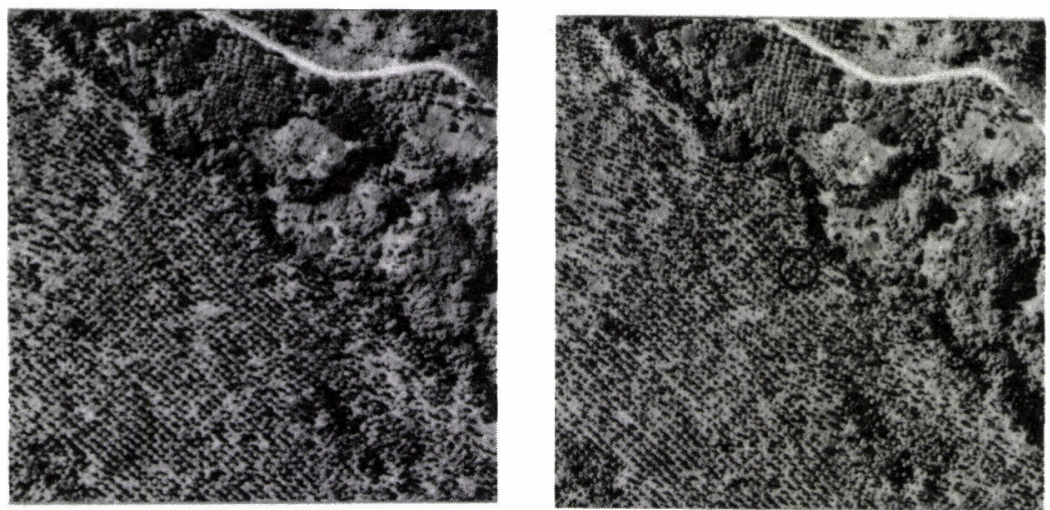

写真一 3 ココナツ林空中写真の一例

撮影縮尺 $1 / 20,000 ， 2$ 倍伸し写真

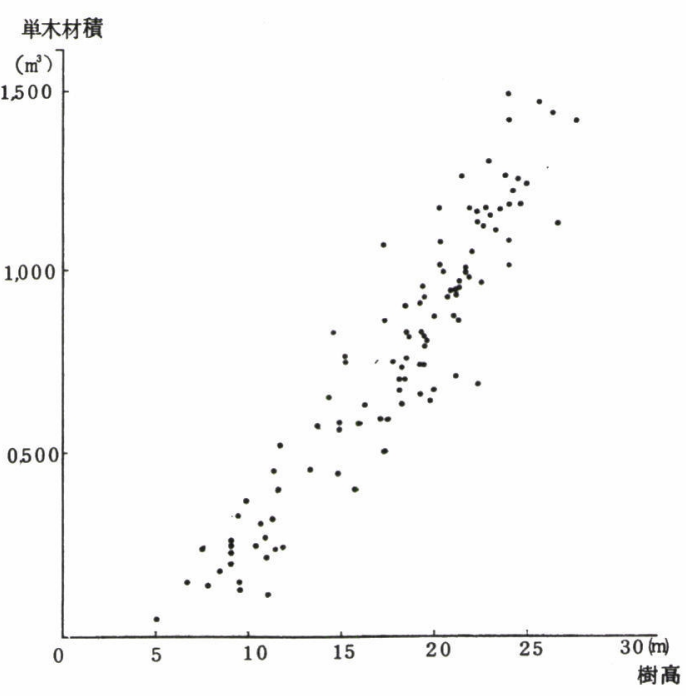

図一 3 材積と樹高の相関（ココナッ）

因を樹高, 樹冠直径とし, 標本木の現地調査のデータ を用いて相関図を作成してみた。図一 $3 ， 4$ である。 なお材積は, 実測した葉下高と樹幹中央径を用いて, 別途区分求積で作成したココナツ幹材積表を適用して 求めた。

この図から，樹高は材積に対して相関が高く，要因 として最適であることがわかる。しかし樹冠值径は無 相関に近く空中写真材積表の要因としては適していな いことがわかった。なお林分としての空中写真材積表 を調製する場合は, 要因としてこの他に本数が考えら れる。しかしココナップランテーションに拈けるココ ナッの植栽法は極めて画一的であり (写真- 3 参照)。 かつ植栽間隔が約 $10 \mathrm{~m}$ と疎林（写真－4）のために, これを空中写真上で判読することは極めて容易であり,

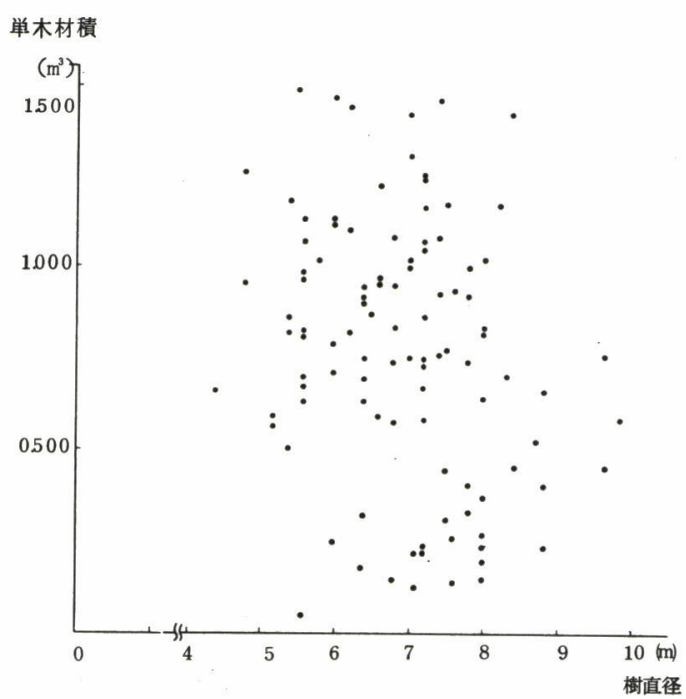

図-4 材樌と樹冠直径の相関

しかもその測定精度は極端なものを除いてはまず完全 に正確に判読できることは明らかであったので，あえ て相関分析は行なわなかった。

\section{5）データの写真上測定と回帰分析}

前項における検討結果から、ココナッの空中写真立 木材積式のための要因としては樹高を用いることとし, 林分を対象とするときはこれに本数を組合わせること が適当と判断された。

以上の検討の上にたって，まず標本木について空中 写真上で樹高を測定した。測定は視差測定桿によって 視差々等を測り，3-4)の項の(1)式用いて計算した。

あてはめる材積式は, 検討の結果 1 要因であること から次のものとした。 


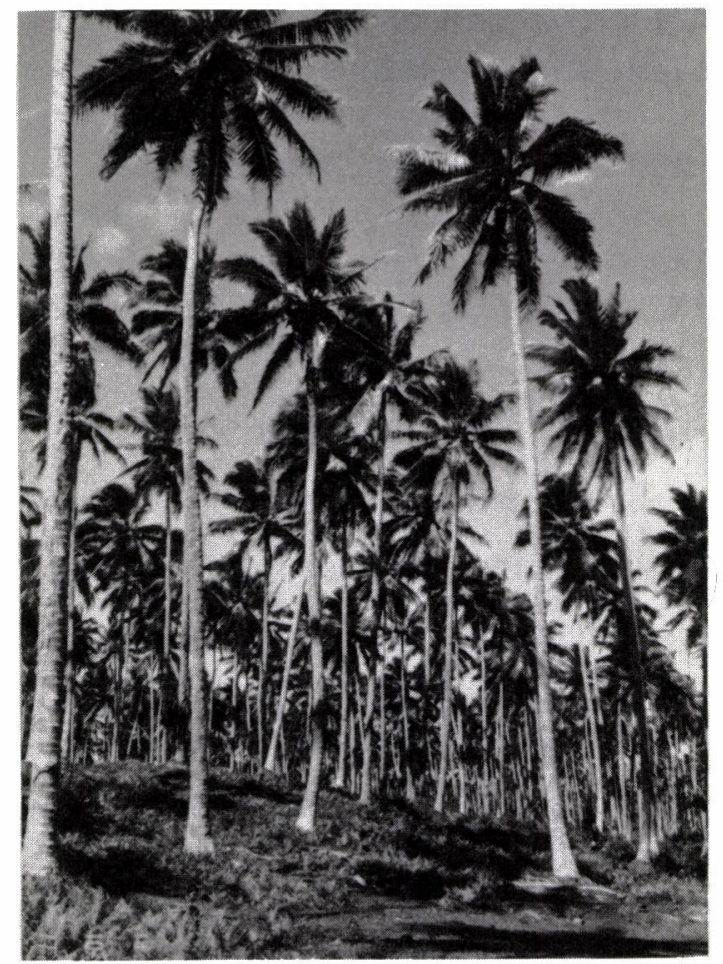

写真-4 ココナツ林の現地写真

空中写真の○印の位置で, 平均樹高 $18 \mathrm{~m}$ 平均樹幹中央高径 $26.2 \mathrm{~cm}$, $h$ a 当り材積 $85 \mathrm{~m}^{\circ}$

$$
\begin{aligned}
\mathrm{v}=\mathrm{a} \mathrm{h} \mathrm{h}^{2}+\mathrm{bh}+\mathrm{c} \quad \mathrm{v}: \text { 単木材積 (実測值) } \\
\quad \mathrm{h}: \text { 樹高 }
\end{aligned}
$$

6)分析の結果

回帰分析の結果得られた材積式は次の通りである。 $\mathrm{v}=-0.0000586 \mathrm{~h}^{2}+0.0640992 \mathrm{~h}-0.318162$ (重相関係数 0.8601 )

これによると, パラメータ a ( $\mathrm{h}^{2}$ の係数) はほ に近く，実質的には直線回帰であると想定される。

精度としては重相関倸数に拈いて 0.86 とメルクシー マッよりもや〉覀い結果となった。これはココナッを 材として利用することを目的とした分析は初めてであ り，どのデータが異常データとして衰却すべきかとい った基準が決め難く，結局採取したサンプルの全デー タを使用したためである。また樹高という１要因から 材積式を推定している点にも問題はあろう。今後他の 要因も検討してゆく必要があると思われる。

なおこの材積式のデータのレンジは次の通りである。

$\mathrm{v}: 0.1355 \leqq \mathrm{v} \leqq 1.6436 \mathrm{~m}^{3}$

$\mathrm{h}: \quad 5.4 \leqq \mathrm{~h} \leqq 26.1 \mathrm{~m}$
SPECIES: COCONUT

AREA : TAVEUNI, FIJI

\begin{tabular}{|c|c|c|c|c|c|c|c|c|c|c|c|c|c|c|c|c|c|}
\hline \multirow{2}{*}{$\mathrm{H}(\mathrm{m})$} & \multirow{2}{*}{$\mathrm{N}$} & \multicolumn{16}{|c|}{ NUMBER OF TREES/HA (MEASURED BY PHOTO-INTERPETATION) } \\
\hline & & 4 & 8 & 12 & 16 & 20 & 24 & 28 & 32 & 36 & 40 & 44 & 48 & 52 & 56 & 60 & 64 \\
\hline \multirow{16}{*}{ 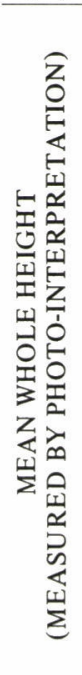 } & 5 & - & - & - & - & - & - & - & - & - & - & - & - & - & - & 0.1 & 0.1 \\
\hline & 6 & 02 & 0.5 & 0.8 & 1.0 & 1.3 & 1.5 & 1.8 & 2.1 & 2.3 & 2.6 & 2.8 & 3.1 & 3.3 & 3.6 & 3.9 & 4.1 \\
\hline & 7 & 0.5 & 1.0 & 1.5 & 2.0 & 2.6 & 3.1 & 3.6 & 4.1 & 4.6 & 5.1 & & 6.1 & 6.6 & 7.1 & 7.7 & 8.2 \\
\hline & 8 & 0.8 & 1.5 & 2.3 & 3.1 & 3.8 & 4.6 & 5.3 & 6.1 & 6.9 & 7.6 & 8.4 & 9.2 & 9.9 & 10.7 & 11.5 & 12.1 \\
\hline & 9 & 1.0 & 2.0 & 3.0 & 4.1 & 5.1 & 6.1 & 7.1 & 8.1 & 9.1 & 10.2 & 11.2 & 12.2 & 13.2 & 14.2 & 15.2 & 16.3 \\
\hline & 10 & & & & & 6.3 & & & 10.1 & & & & & 16.5 & & 19.0 & 20.0 \\
\hline & 11 & & 3.0 & 4. & 6.1 & 7.6 & 9.1 & 10.6 & 12.2 & 13.7 & 15.2 & 6.7 & 8.2 & 19.8 & 21.3 & 22.8 & 24.3 \\
\hline & 12 & 1.8 & 3.5 & 5.3 & 7.1 & 8.9 & 10.6 & 12.4 & 14.2 & 15.9 & 17.7 & 19.5 & 21.2 & 23.0 & 24.8 & 26.6 & 28.3 \\
\hline & 13 & 2.0 & 4.0 & 6.1 & 8.1 & 10.1 & 12.1 & 14.1 & 16.2 & 18.2 & 20.2 & 22.2 & 24.3 & 26.3 & 28.3 & 30.3 & 32.3 \\
\hline & 14 & & 4.5 & & 9.1 & 11.4 & 12 & 15.9 & 18.2 & 20.4 & 22.7 & 25.0 & 27.3 & 29.5 & 31.8 & 34.1 & 36.3 \\
\hline & 15 & & 5.0 & 7.6 & 10.1 & 12.6 & 15.1 & 17.6 & 20.2 & 22.7 & 25.2 & & 30.2 & 32.8 & 35.3 & 37.8 & 40.3 \\
\hline & 16 & & 5.5 & 8. & 11.1 & 13.8 & 16.6 & 19.4 & 22.2 & 24.9 & 27.7 & 30.5 & 33.2 & 36.0 & 38.8 & 41.5 & 44.3 \\
\hline & 17 & 3.0 & 6.0 & 9.1 & 2.1 & 15.1 & 18.1 & 21.1 & 24.1 & 27.2 & 30.2 & 3 & 36.2 & 39.2 & 42.3 & 45.3 & 48.3 \\
\hline & 18 & & 6.5 & 9.8 & 13.1 & 16.3 & 19.6 & 22.9 & 26.1 & 29.4 & 32.7 & 35.9 & 39.2 & 42.5 & 45.7 & 49.0 & 52.3 \\
\hline & 19 & 3.5 & 7.0 & 10.5 & 14.1 & 17.6 & 21.1 & 24.6 & 28.1 & 31.6 & 35.1 & 38.7 & 42.2 & 45.7 & 49.2 & 52.7 & 56.2 \\
\hline & 20 & 3.8 & 7.5 & 11.3 & 15.0 & 18.8 & 22.6 & 26.3 & 30.1 & 33.9 & 37.6 & 41.4 & 45.1 & 48.9 & 52.7 & 56.4 & 60.2 \\
\hline
\end{tabular}

(UNIT: $\mathrm{m}^{3} / \mathrm{ha}$ )

表一 6 空中写真材積表 (ココナッ) の一部 
7 ）材積表の調製

材積表の調製は，1要因による場合は簡単である。 そのため，林分材積表としても使えるように，樹高の ほかに本数を組合わせた 2 要因材積表として調製した。 この場合, 本数は4)に述べたような理由から実数を使 えばよいし，林分構造がほメ゙一斉林で単純なことから 単木樹高を平均樹高と置換えることも可能であるから, 結局単木材積を本数すればよい。すなわち材積式は次 の通りである。

$$
\begin{aligned}
\mathrm{V}= & \mathrm{N}\left(-0.0000586 \mathrm{H}^{2}+0.0640992 \mathrm{H}\right. \\
& -0.318162)
\end{aligned}
$$

$\mathrm{N}$ : 本数, 単木の場合は 1

$\mathrm{H}$ : 樹高, 林分の場合は平均の樹高

調製した空中写真材積表の一部を表一 6 に例示する。

\section{5.おわりに}

空中写真材積表の作成は，国内の森林に対しては既 に十数年前から実施されているが ${ }^{9}$, 熱帯林のものに ついては例をみない。しかし現在の日本の森林資源の 賦存状況を考えるとき, 気候的にも有利な森林資源培 養の素地をもつ熱帯の発展途上国との友好を深め, ス ムーズな木材供給源の確保をはかる必要があろう。そ のためにも森林資源の情報を正しく把握する技術協力
は欠かせないことであり，今後ともこの例のような空 中写真材積表が数多く検討され，整備されることを望 むものである。

最後に, この調査結果は, 国際協力事業団による, 「インドネシア国中部ジャワ州プカロニガン林業資源 調査」, および「フィジー国タベウニ島ココナツ林解析 調査」の一部であることを付記し, 謝意を表する。

(1978.7.10 受付)

\section{引用および参考文献}

1）日本林業技術協会編：「森林航測ハンドブック」p.1〜 10 (1970)

2) 山口夏郎:「昭和 52 年度森林航測関係予算案の概要」 雑誌森林航測第115号, p. 3 4 (1977)

3) 渡辺 宏:「最近の森林判読事業」, 本誌第 $X$ 巻第 1 号, p. $1 \sim 6(1971)$

4）北見営林局計画課, 日林協開発部：「風致を考慮した森 林施業への航測技術の活用」, 林業技術誌第 383 号, p. $14 \sim 17$ (1972) など

5）林野庁: 「林業白書, 昭和 52 年度」p. 39,47 (1978)

6）渡辺 宏:「諸国林業事情ーフィジー一」，林業技術誌 第430号, p. 42〜43 (1978)

7）渡辺 宏:「森林航測テキストブック」p. 148〜 150 (1974)

8) Ministry of Foreign Affairs, New Zealand "Coconut Stem Utilization Seminar” P.13 297 (1976)

9）中島 巌：「森林航測概要」p.162（1961）など 